\title{
Concomitant Medication Start Time
}

National Cancer Institute

\section{Source}

National Cancer Institute. Concomitant Medication Start Time. NCI Thesaurus. Code C83130.

The time at which the concomitant medication usage begins. 